\title{
Earthquake hazard mitigation analysis of the pier 231 Harbour Road Bridge
}

\author{
N. Retno Setiati ${ }^{1, *}$ and Ireng Guntorojati ${ }^{2}$ \\ ${ }^{1}$ Institute of Road Engineering, Ministry of Public Works and Housing, 40294 Bandung Jawa Barat, Indonesia \\ ${ }^{2}$ PT. Wiratman Chodai Indonesia, 12540 Jakarta, Indonesia
}

\begin{abstract}
Earthquake mitigation for infrastructure, especially bridges, needs to be done to avoid collapse of the bridge structure under earthquake load. The investigation and rehabilitation of existing bridges against earthquake hazards needs to be carried out through a screening process based on The Bridge Inspection Guidelines (Pd No.005-01/P/BM/2011). Based on the results of the inspection and the screening process, it can be determined whether the bridge is able to resist earthquake loads during its service lifetime or needs to be strengthened. This study aims to determine the strength capacity of Harbour Road bridges in resisting earthquake loads based on SNI 28332016 and Peta Gempa Nasional 2017 during its service lifetime. Analysis of the pushover structure was carried out at Pierhead 231 which is located on the WiyotoWiyono Harbour Road,Jakarta. The modeling of Harbour Road bridge structure in longitudinal direction consists of piers and concrete girder separated by expansion joint and bearing, while in transverse direction is modeled as a single pier system. Structural analysis modeling is assumed to behave as a system with single degree of freedom (SDOF). Based on the results of pushover analysis, it can be seen the location and level of plastic hinge that occur when the performance point is reached. During design earthquake conditions, the performance point is obtained in the Immediate Occupancy condition and the plastic hinge occurs first at the bottom of the Pier. Structural performance at the time of the earthquake design is still under life safety conditions so the Harbour Road bridge still meets the strength requirements.
\end{abstract}

\section{Introduction}

\subsection{Background}

Indonesia is a country prone to natural disasters, in terms of geological, climatological and social demographic aspects. Based on geological aspect, the Indonesian archipelago is located in the Pacific Ring of Fire, which curves from Sumatra, Java, Nusa Tenggara, and North Sulawesi, which makes it prones to earthquakes and volcanic eruptions. One of the recent biggest earthquake that occurred in 2018 in Central Sulawesi was of magnitude 7.7 which also caused tsunami waves. Indonesia is one of the largest earthquake-prone country that can also experience tsunami waves.

In addition to high number of casualties, numerous road and bridge infrastructure were also damaged by the earthquake. Evaluated from the aspect of structural strength, buildings in Indonesia (including bridges) that were constructed in the 1970 s have not sufficiently considered the aspects of earthquake load [6]. For this reason, an inventory and examination of existing bridges is needed to determine the strength of the bridge capacity during its service life time. This study aims to determine the strength of the capacity of existing bridges in its service lifetime in resisting earthquake loads calculated using Peta Gempa Nasional 2017[9]. The case study used is the pier structure of P231 Harbour Road bridge which is located on the Wiyoto Wiyono Tanjung Priok Harbour Road in Jakarta.

\subsection{Literature review}

Earthquakes with great strength have recently occurred in Indonesia. The earthquakes that occur are inseparable from very active tectonic conditions. Indonesia has been hit by many destructive earthquakes and is often followed by devastating tsunami waves [8]. The occurrence of earthquakes in DKI Jakarta in 2007 and 2009 warned stakeholders of the need to prepare infrastructure buildings to withstand strong earthquake forces [10]. According to Pradono [11], the intensity of the DKI Jakarta earthquake was MMI VII for the 500year earthquake, and MMI VIII for the 1,000 and 2,500 annual earthquakes. The earthquake events in Jakarta in 2007 and 2009 with the intensity of MMI V were small compared to the intensity of the threat of earthquakes that could occur in Jakarta according to the Earthquake Hazard Map. To anticipate the occurrence of infrastructure damage due to the earthquake, especially in DKI Jakarta, it is necessary to assess the condition. One of them is the assessment of the condition of the toll road and the Harbour Road bridge.

* Corresponding author: retno.setiati@pusjatan.pu.go.id 
Harbour Road is an elevated toll road that was built in 1995 with a design that refers to the 1992 BMS Earthquake Regulation. The regulation has now been revised with the latest SNI 2833-2016 earthquake regulations (Bridge planning for earthquake loads), as well as the Peta Gempa Nasional 2017. The bridge structure used is in the form of reinforced concrete pier, prestressed girder, and concrete slab. Based on secondary data obtained from PT. CMNP, the technical data of the P231 pier structure are as follows:

- span length : 35 meters

- wide span bridge : 9 meters

- compressive strength (fc') : $29 \mathrm{MPa}$

- tensile yield (fy) : $390 \mathrm{MPa}$

- number of girder : 10 girders

- weight per girder : 65,625 tons

- total weight of pierhead : 512,5 tons

- total weight of the girder : 656,25 tons

- weight of diaphragm : 46,875 tons

- weight of barrier and asphalt :113,75 tons

- weight of slab : 546,875 tons

- total weight of the upperstructure : 1876.25 tons

The schematic form of the pier structure P231 is shown in Fig. 1 up to Fig. 3.

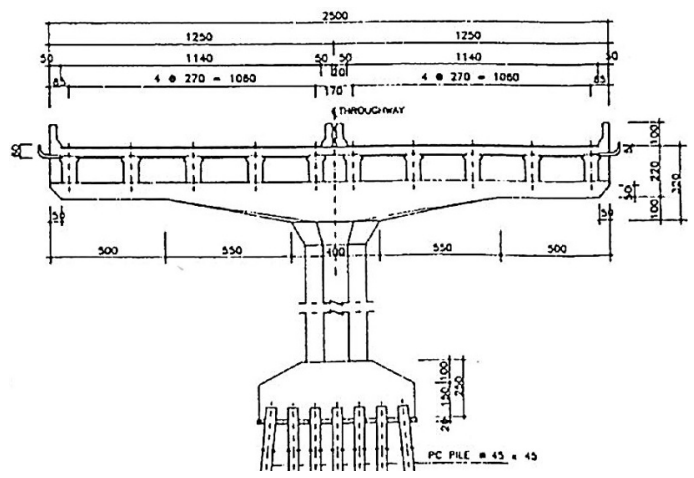

Fig. 1. P231 pier cross section scheme.

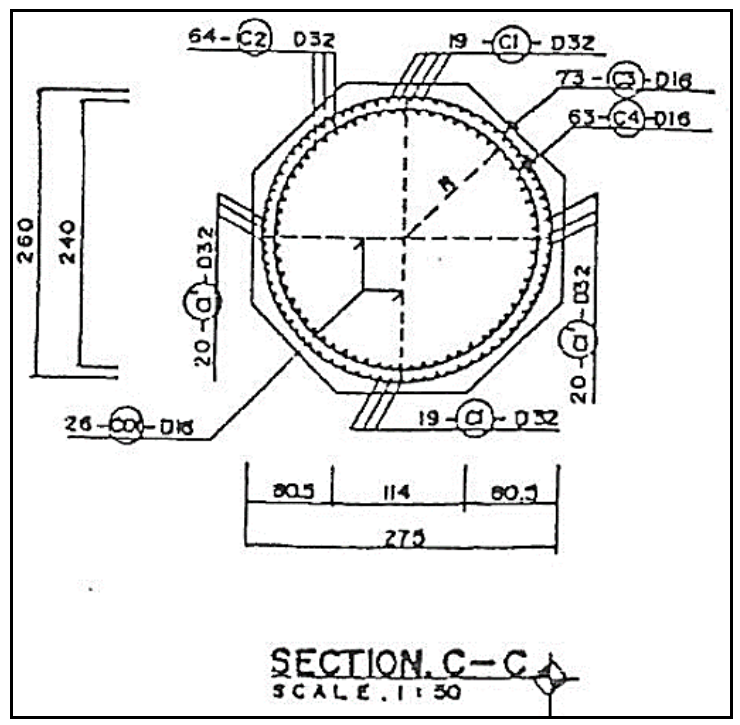

Fig. 2. Dimensions in diameter size of P231 pier section.

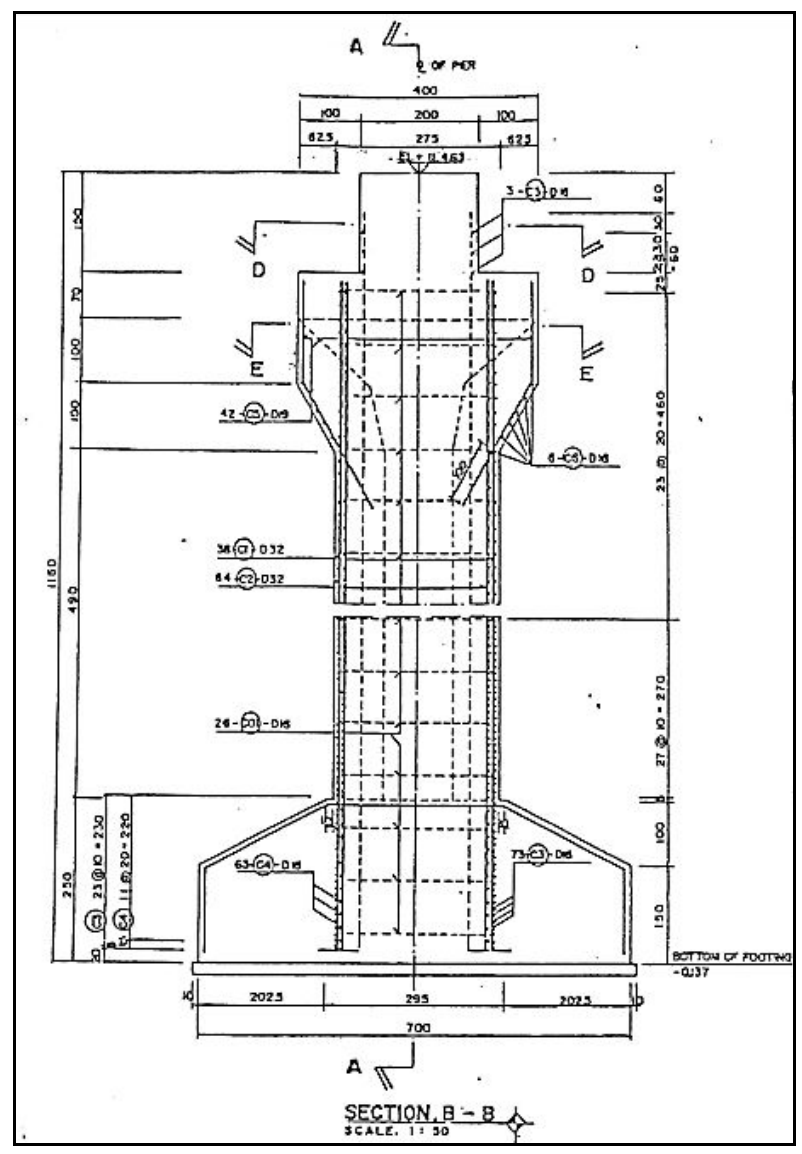

Fig. 3. The high dimensions of the P231 pier section.

Pushover analysis is one component of performance based design which is a method to determine the capacity of a structure $[1,2,7]$. The basis of this method is to give a certain static load pattern in the lateral direction, which amount is increased incrementally until the structure reaches a certain displacement target or reaches a certain collapse pattern [5]. From the results of the analysis, the relationship between the base shear and the roof displacement can be described, the relationship is then mapped as a structural capacity curve [12]. In addition, pushover analysis can also show visually the behavior of structures when elastic, plastic conditions and until the occurrence of collapse on the structural elements of the structure are considered as static loads acting at the center of mass [13].

\section{Methodology}

To examine the structure capacity of the renewal of regulations in both SNI 2833-2016[4] and the Earthquake Source and Peta Gempa Nasional 2017, an analysis of the performance of the typical P231 Pier structure on the Harbour Road toll road was carried out using pushover analysis and determination of performance points using software. In the analysis, the pier is modeled as a single pier structure in longitudinal and transverse directions. The foundation structure is assumed to be very rigid and behave like a structure with one degree of freedom (Single Degree of Freedom/SDOF). 


\section{Results and discussion}

Bridge structure in the longitudinal direction is a series of pier and concrete girder separated by a pierhead system and expansion joint in each span. In the transverse direction the bridge structure is a single pier system. Modeling the pier structure P231 is shown in Fig. 4.

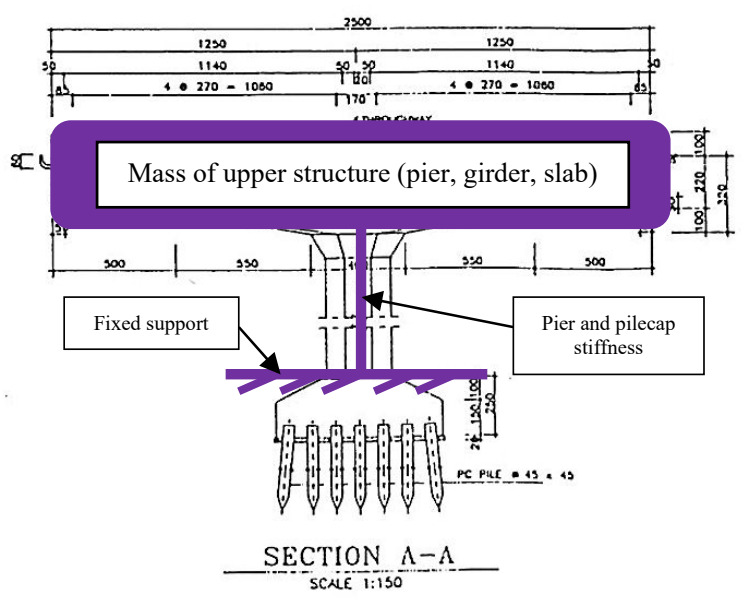

Fig. 4. Modeling of the pier structure of P123.

Based on Fig. 4, the weight of the structure is calculated as mass and as a permanent vertical load that works during an earthquake. By modeling the stiffness and mass of the structure, the frequency and natural period of the structure can be obtained based on the analysis of eigenvalues as shown in Fig. 5.
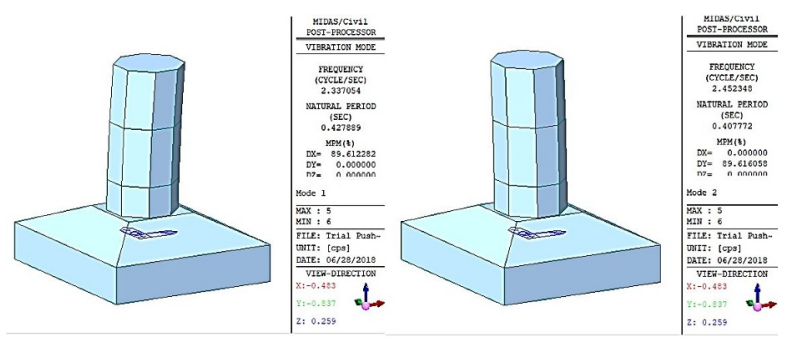

Fig.5. Frequency and natural period of mode structure $1(0.42$ s) and mode $2(0.40 \mathrm{~s})$.

Table 1. Earthquake design Pier 231.

\begin{tabular}{|c|c|c|c|}
\hline \multicolumn{4}{|c|}{ The North Jakata } \\
\hline Ie & 1 & Fa & 1.7 \\
\hline \multicolumn{2}{|c|}{ Site class SE } & Fv & 3.2 \\
\hline PGA & 0.25 & Sds & 0.850 \\
\hline Ss & 0.5 & Sd1 & 0.640 \\
\hline S1 & 0.2 & T0 & 0.151 \\
\hline FPGA & 1.45 & Ts & 0.753 \\
\hline
\end{tabular}

The design earthquake used is a demand from pushover analysis carried out based on SNI 2833-2016 and Peta Sumber dan Bahaya Gempa Tahun 2017. Location of the structure is in the North Jakarta area assuming the bridge is located on a soft land location (SE) [3]. The earthquake parameters are made based on the response of the spectra in Table 1 described in Fig. 6

Based on Table 1, the specific earthquake design response spectra for the North Jakarta region can be constructed as shown in Fig. 6.

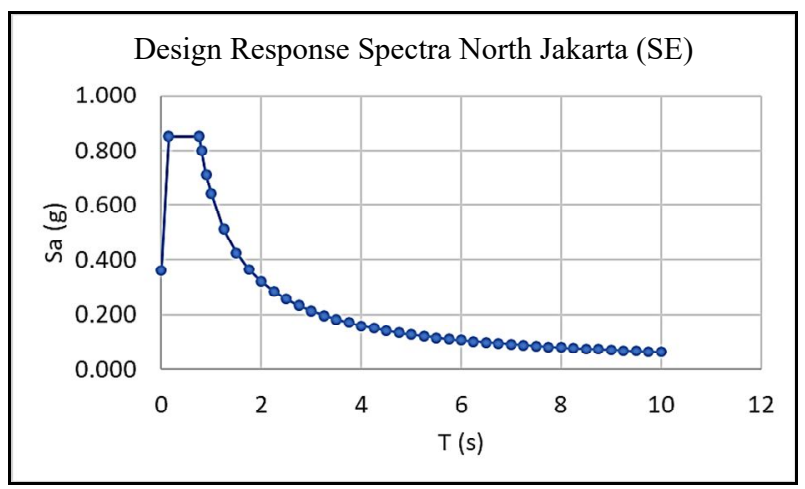

Fig.6. Spectral design response of the North Jakarta area (SE).

\subsection{Bridge inelastic material modeling}

Inelastic behaviour of concrete and reinforcing steel materials are assumed in the model. Modeling concrete structural elements using the Mander model with the assumption of reinforced concrete is not unconfined. The characteristic strength of the concrete used is fc '29 MPa (Fig. 7).

Based on Fig. 5, for confined concrete with the Mander model used in the construction of stirrup reinforcement (2D16-100). Modeling of reinforcing steel material is shown in Fig. 8.

Fig. 8 is a BJTD-40 bilinear steel and strain hardening modeling behavior (fy $390 \mathrm{MPa}$ ).

\subsection{In elastic modeling and plastic hinge of pier cross section}

In the event of an earthquake, the SDOF structure is generally dominant in resisting bending moments and potentially occurs flexural plastic hinge, especially at the bottom of a single cantilever structure pier. To model the in elastic behavior of the pier structure an analysis of the curvature moment on the cross section using previously defined concrete material and reinforcement. The form of analysis of the moment of curvature is shown in Fig. 9.

Based on Fig. 9, from the analysis of pier cross section curvature moment the main points of pier behavior are in the form of melting and ultimate points to model plastic hinge behavior. Plastic hinge is defined based on FEMA, with reference to the value of melting moment and melting rotation and ultimate moment and ultimate rotation. The definition of plastic hinge is assumed to be the same for the longitudinal and transverse direction of the bridge because the dimensions and reinforcement of the pier are symmetrical. Plastic 
hinge are defined at the lower end and upper end of the pier as shown in Fig. 10.

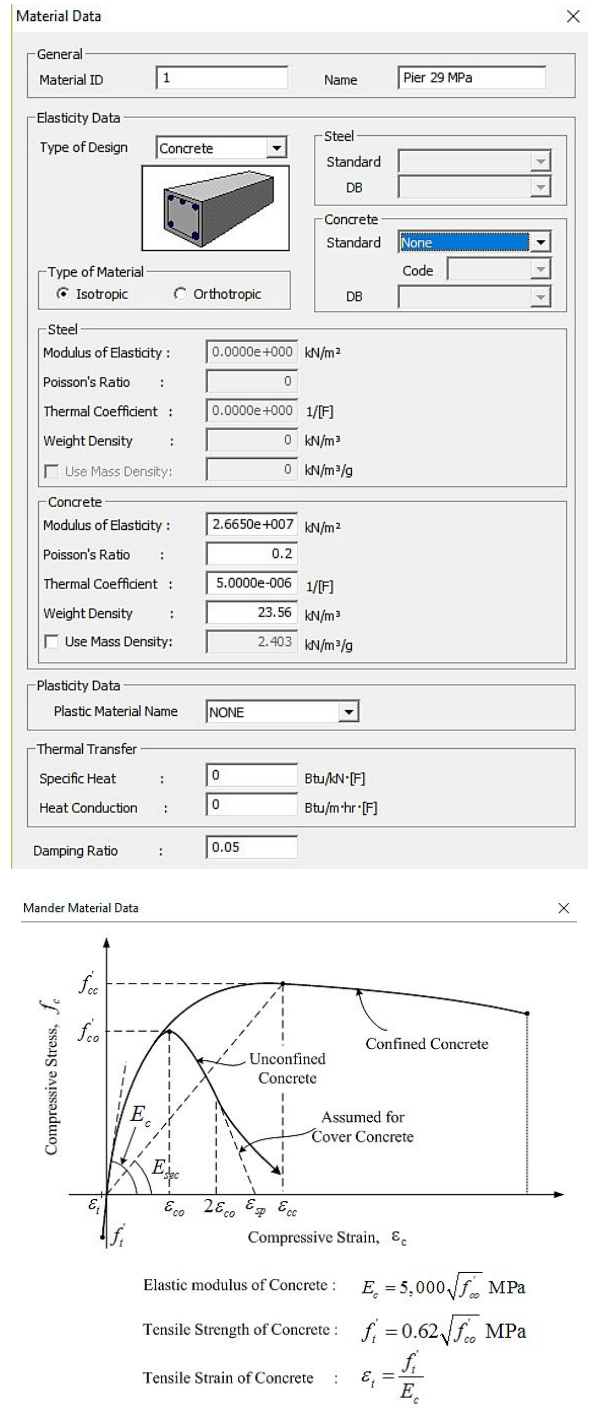

Fig.7. Modeling of unconfined concrete material.

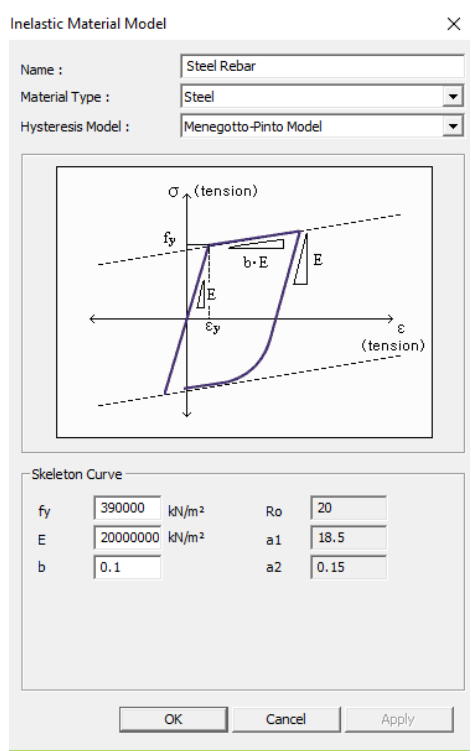

Fig.8. Modeling of reinforcing steel.

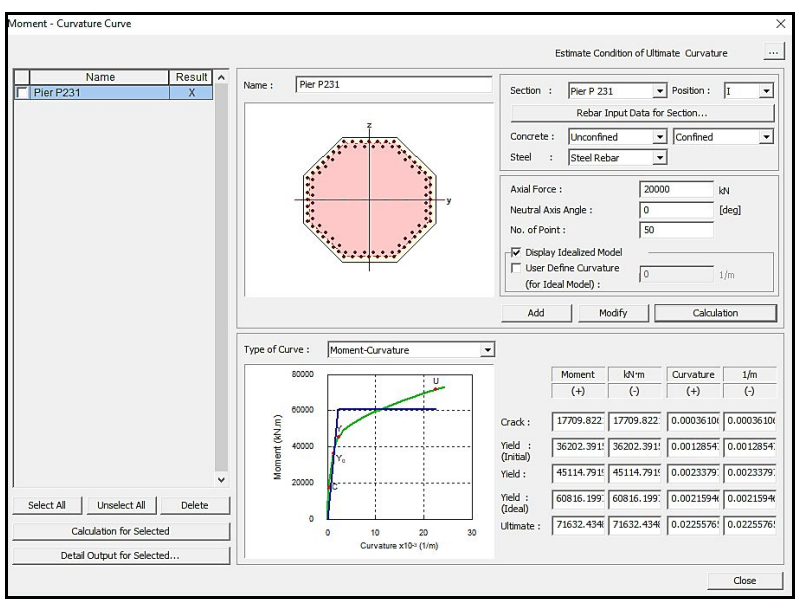

Fig.9. Analysis of moments curvature.
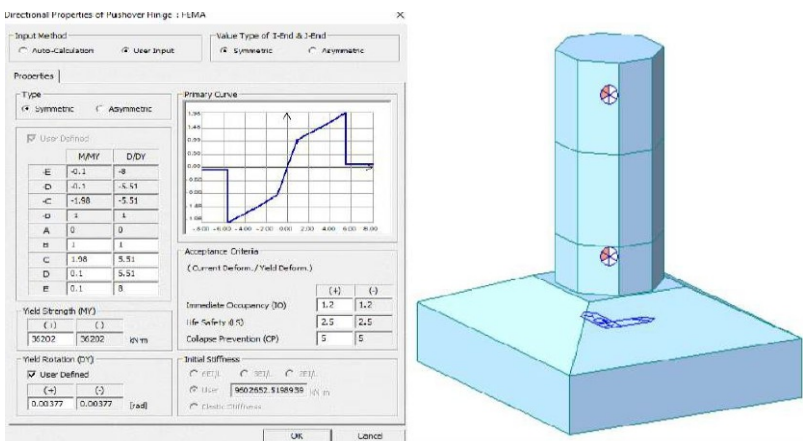

Fig.10. Defining and location of plastic hinge.

Pushover analysis is performed by defining a load pattern in the longitudinal and transverse direction of the bridge at the location of the center of mass of the upper structure as shown in Fig. 11.
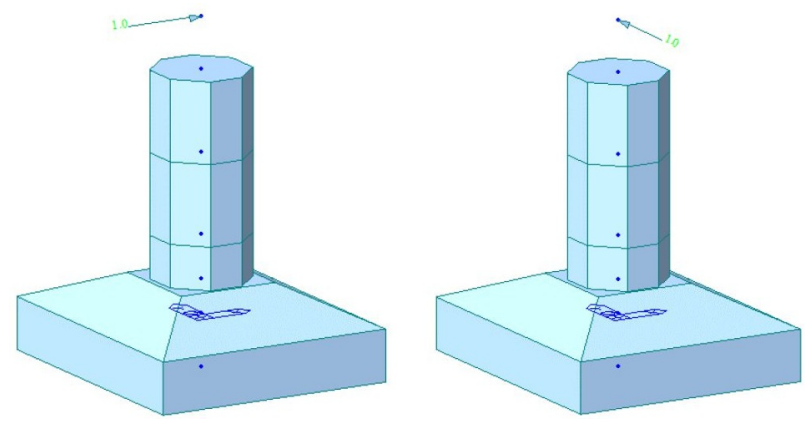

Fig.11. Load pattern at the location of the center of the upper structure mass.

Before pushover analysis is carried out, the permanent load that works during the service period or construction period must be initialized. Defining a pushover case is done by increment method so that pushover analysis will be carried out until the displacement at the center of mass reaches $0.25 \mathrm{~m}$. Pushover analysis is carried out for each longitudinal and transverse direction. Based on the results of the pushover analysis, the capacity curve obtained is a description of the behavior of the structure from the elastic, inelastic stage, until the structure collapses in the form of a graph of the relationship between the base shear and the deviation of the structure at the specified location (center 
point of the upper structure). Fig. 10 is the capacity curve for pushover analysis in the longitudinal and transverse direction of the bridge.
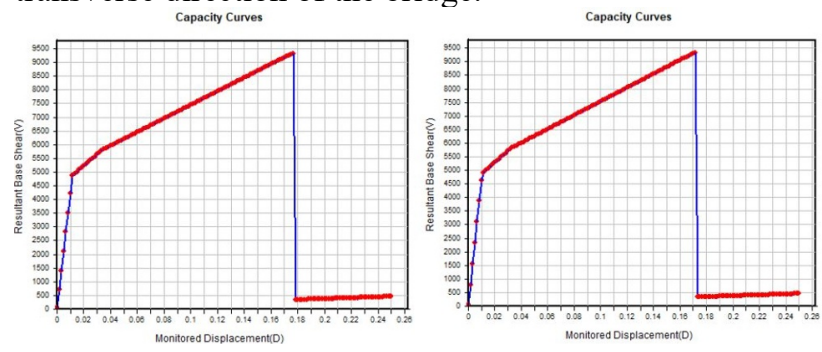

Fig. 12. The capacity curve for the longitudinal and transverse directions of Pier 231.

Based on Fig. 12 the results of the pushover analysis obtained for the longitudinal and transverse directions of the bridge are almost the same as the modeling of the symmetrical elements. To obtain structural behavior and performance at the time of earthquake design, a performance point analysis based on FEMA is needed. Performance point analysis is performed by changing the capacity curve to spectra of capacity and looking for intersection points with earthquake design (demand). The performance point for longitudinal direction analysis are shown in Fig. 13.

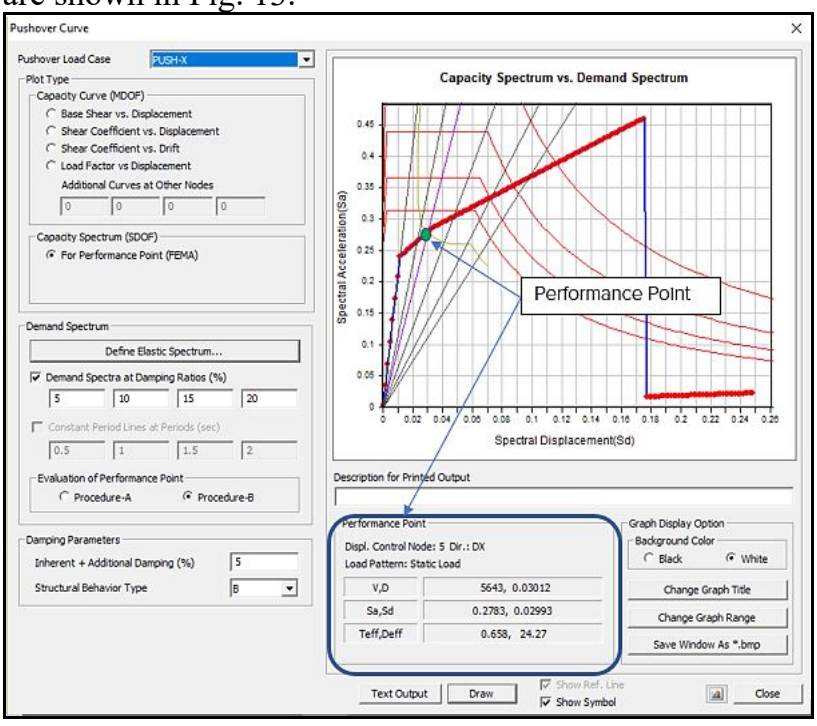

Fig.13. Pier structure point performance.

Based on Fig. 13, the structural performance point is obtained after the structure undergoes inelastic deformation exceeding yield capacity. Performance points are obtained under the following structural conditions :

- Base shear force : $5643 \mathrm{kN}$

- Deviation : $0.03 \mathrm{~m}$

- Sa : 0.278

- Sd: 0.029

- TEFF : $0.658 \mathrm{~S}$

- Deff : $24.2 \%$

From the results of pushover analysis the location and level of Plastic hinge that occur when the performance point is reached can be reviewed as shown in Fig. 14.

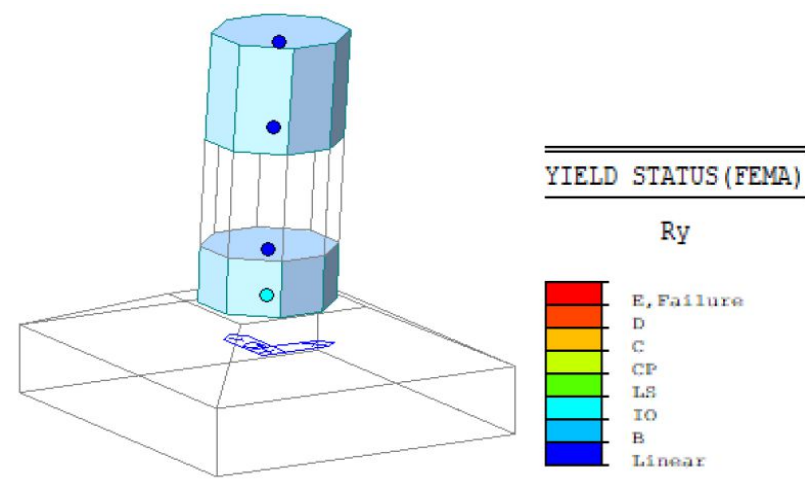

Fig. 14. Plastic joint conditions at the performance point of Pier 231.

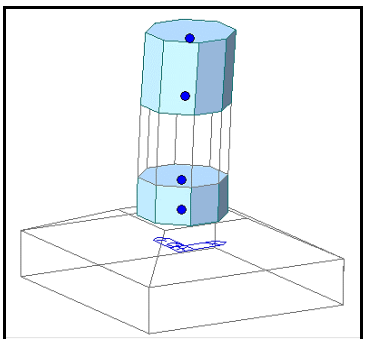

(a) Step 1 (linier)

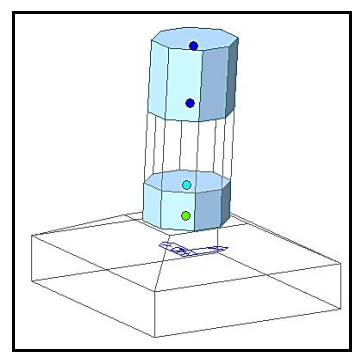

(c) Step 50 (LS)

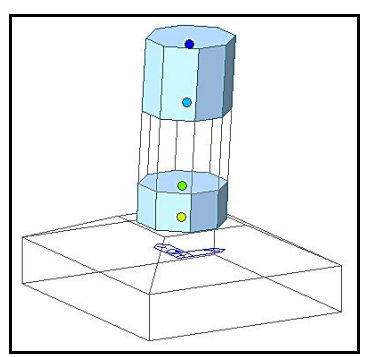

(e) Step 105 (CP)

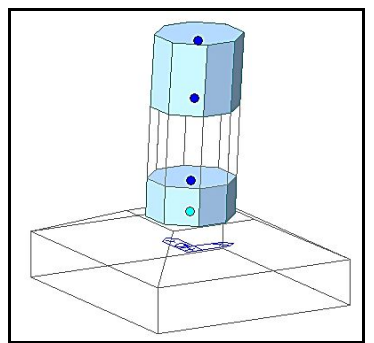

(b) Step 18 (PP-IO)

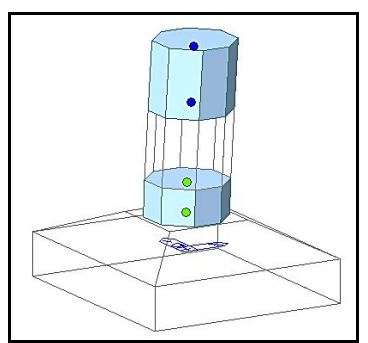

(d) Step 75 (LS)

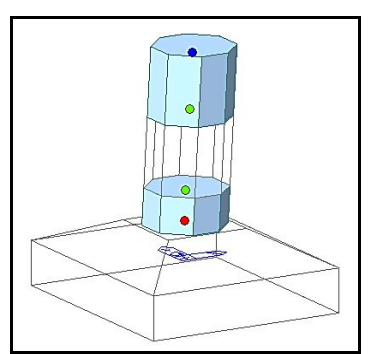

(f) Step 110 (collapse)
Fig. 15. Mechanism of collapse and the occurrence of plastic hinge.

From pushover analysis, the stages of structural collapse mechanism at each pushover stage from the linear stage to the collapse can be reviewed as shown in Fig. 15. Based on Fig. 15, the results obtained at the $18^{\text {th }}$ step performance point is shown in Table 2. 
Table 2. The result of pushover analysis.

\begin{tabular}{|c|c|c|}
\hline Step & $\begin{array}{c}\text { Spectral displacement } \\
(\mathrm{Sd})\end{array}$ & $\begin{array}{c}\text { Spectral acceleration } \\
(\mathrm{Sa})\end{array}$ \\
\hline 0 & 0.0001656 & 0.0034674 \\
\hline 1 & 0.0016560 & 0.0346745 \\
\hline$\ldots$. & $\ldots \ldots$ & $\ldots \ldots$ \\
\hline 17 & 0.0281517 & 0.2746770 \\
\hline 18 & 0.0298077 & 0.2780940 \\
\hline
\end{tabular}

Based on Table 2, in step 18 and the only the plastic hinge at the bottom of the pier that experience a color change that indicates that they have reached the Immediate Occupancy (IO) condition. Whereas plastic hinge in other locations are still at the linear level.

\section{Conclusion}

Based on the obtained analysis results, it can be concluded that the evaluation of the structure of P231 on the Harbour Road toll road was carried out by pushover analysis to determine the performance of the structure against earthquake design conditions. The design earthquake used in the analysis was earthquake based on SNI-2833-2016 and Peta Gempa 2017. Pushover analysis is done by defining plastic hinge and structural inelastic behavior after exceeding the elastic limit. During earthquake design conditions, the performance point was obtained in the immediate occupancy condition, and the plastic joint occurred first at the bottom of the pier. From the analysis that has been carried out the structure performance at the time of the earthquake design is still below the life safety level required by regulations. For further analysis it is necessary to accommodate the stiffness of the structure in the longitudinal direction due to the influence of the girder and the upper structure, reviewing the deformation limits for each level of damage (IO, LS, CP, C) against the latest international reference (FEMA/FHWA), and checking design of the capacity of the structure foundation and pier shear capacity to ensure that the first flexible plastic joint still occurs at the bottom of the pier.

The author would like to thank Mr. Ir. Deded P. Sjamsudin, M.Eng.Sc. as the Head of Institute Road of Engineering and Mr. Joko Purnomo which has provided support for this research activity. Furthermore, the authors also wish to thank Mr. Wawan Witarnawan, Mr. Abinhot Sihotang, and Mr. Samun Haris as a resource person who has given the science is very helpful to the author.

\section{References}

1. Comartin, Craig D, dan C. Rojahn, ATC-40 Seismic evaluation and retrofit of concrete buildings $\mathbf{1}$. (1996).

2. R.D.Sandhi, A. Wibowo, A. Smd, University Brawijaya J. 1 (3) (2012)

3. B.M. Hutapea, I. Mangape. Civil Eng. J. 16 (3) (2009)

4. Indonesia, Standar Nasional, dan Badan Standardisasi Nasional, Perencanaan Jembatan Terhadap Beban Gempa (SNI 2833:2016)

5. N.I. Desmonda, A. Pamungkas, POMITS Eng. J. 3 (2) (2014)

6. R.A. Kadarusman, A. Smd, A. Wibowo. University Brawijaya J. 1 (3) (2017)

7. M. Ichsan, R. Yulija, and R. Mulyani. Pushover Analisis Performance Evaluation Seismic Structure, (2012).

8. H.S. Nuryanto, Science and Technology Ind. J. 10 (2) 71-77 (2008)

9. Kementerian Pekerjaan Umum dan Perumahan Rakyat, Peta Sumber dan Bahaya Gempa Indonesia Tahun 2017.

10. M.H. Pradono, O. Rovara, Q. Zahro, Sciences and Mitigation of Hazard Tech. J. 13 (2) 89-95 (2018)

11. M.H. Pradono, Alami. J. 1 (1). 49-54 (2017)

12. H.Y. Mamesah, S.E. Wallah, and R.S. Civil Static. J. 2 (4) 214-224 (2014)

13. Muhaimin, B. Tjahjono, Darmawan, Tan. Lingk. J. 18 (1) 28-34 (2016) 